\title{
To Ban or Not to Ban? Reviewing an Ongoing Dilemma on Sea Turtle Egg Trade in Terengganu, Malaysia
}

OPEN ACCESS

Edited by:

Edward Jeremy Hind-Ozan, Department for Environment, Food and Rural Affairs, United Kingdom

Reviewed by:

Lydia Chi Ling Teh,

The University of British Columbia,

Canada

Hector Barrios-Garrido, University of Zulia, Venezuela

*Correspondence:

Jarina Mohd Jani

jarina@umt.edu.my

tORCID:

Jarina Mohd Jan orcid.org/0000-0002-2126-7025

Specialty section:

This article was submitted to

Marine Conservation

and Sustainability,

a section of the journal

Frontiers in Marine Science

Received: 11 November 2018

Accepted: 25 November 2019

Published: 09 January 2020

Citation:

Mohd Jani J, Jamalludin MA and

Long SL (2020) To Ban or Not

to Ban? Reviewing an Ongoing Dilemma on Sea Turtle Egg Trade

in Terengganu, Malaysia.

Front. Mar. Sci. 6:762.

doi: 10.3389/fmars.2019.00762

\author{
Jarina Mohd Jani ${ }^{1,2 * x}$, Muhammad Allim Jamalludin ${ }^{1}$ and Seh Ling Long ${ }^{3}$ \\ ${ }^{1}$ Faculty of Science and Marine Environment, Universiti Malaysia Terengganu, Kuala Terengganu, Malaysia, ${ }^{2}$ Institute \\ of Tropical Biodiversity and Sustainable Development, Universiti Malaysia Terengganu, Kuala Terengganu, Malaysia, \\ ${ }^{3}$ Institute of Oceanography and Environment, University of Malaysia Terengganu, Kuala Terengganu, Malaysia
}

Legal trade in sea turtles and their eggs remains a reality in many countries where conservation of this marine endangered species does exist. This duality is a conflict to some who appeal for a total trade ban, which may have implications on local livelihoods. Using the Sustainable Livelihoods Approach (SLA), this paper considers the dilemma by empirically examining the context of the state's legislation, particularly the Terengganu Turtle Enactment (TTE) and its "haves" - what is legally provided on paper, the available capitals in hand, and the actual implementation carried out in practice - to elucidate whether a trade ban is indeed the immediate solution for improving sea turtle conservation in the state of Terengganu, Malaysia, which is an important rookery in Southeast Asia. Findings based on data collected through extensive archival research and in-depth interviews with officers of the state who manage sea turtles as well as those whose past and current livelihoods depend on the trade indicate that (1) sea turtles are a transformative natural capital that the Terengganu legislation supports on paper via a pro-conservation concession system; (2) in putting paper into practice, those involved in its implementation have strategically mobilized available resources to achieve a balanced outcome between conservation and livelihood; and (3) institutional absenteeism, financial handicap, and ambiguous legal protection status of nesting beaches are issues that need addressing to fulfill the true potential of this legislation. However, a better conservation outcome is administratively possible via a full conservation-concession system that lists all beaches under the TTE to ensure the sustainability of sea turtles and local livelihoods, in preparation for the ultimate longterm goal: total conservation via a trade ban without which conservation of the species remains precarious not only at state but also at national and regional levels.

Keywords: sea turtle conservation, turtle egg concession, Terengganu, trade ban, Southeast Asia, sustainable livelihoods approach

\section{INTRODUCTION}

Sea turtles are an iconic megafauna that are now protected from international trade in 178 signatory countries of the Convention on International Trade in Endangered Species of Wild Fauna and Flora (CITES) (Humber et al., 2014). The seven known species of sea turtles, leatherback turtle (Dermochelys coriacea), loggerhead turtle (Caretta caretta), flatback turtle (Natator depressus), olive ridley turtle (Lepidochelys olivacea), Kemp's ridley turtle (Lepidochelys kempii), green turtle 
(Chelonia mydas), and hawksbill turtle (Eretmochelys imbricata), are, however, within the national boundaries of the countries where they occur, subject to different levels of protection, often depending on the local sea turtle-human interaction context (Frazier, 2003). In many important sea turtle rookeries in the world, traditional consumption of either their eggs, meat, or both are legally protected (Campbell, 2010; Garland and Carthy, 2010; Grayson et al., 2010), while their shells continue to be a popular commodity in East Asian markets (Lam et al., 2011). Furthermore, there is also an increasing demand for allowing cultural use in countries where total protection is provided (Rudrud, 2010). Along the West African coast where they are consumed not only for food but also as an important ingredient for traditional healing, Fretey et al. (2007) suggested that exemption be given for cultural uses. Due to the significance of their consumptive use in some indigenous communities, it is defended as a cultural right that makes legal prohibitions problematic (Barrios-Garrido et al., 2017). These various instances of legal consumptive use of sea turtles and calls made in their favor often do not sit well among conservationists, where they are denounced as pejorative, not complimentary elements to sea turtle sustainability (Campbell, 2002; WWFMalaysia, 2015). In the case of Malaysia, an important sea turtle rookery in Southeast Asia where four species occur, a conservation versus concession debate rages on due to the legal trade of sea turtle eggs that is claimed to impede the sustainability of the megafauna in the country (WWF-Malaysia, 2012).

In Malaysia, sea turtle eggs have always been the only consumed animal part (Hendrickson and Alfred, 1961; Chan and Liew, 1996) that have been locally traded and regulated by local laws before the colonial era (Hendrickson, 1958). Since Malaysia’s independence, every state in Peninsular Malaysia may exercise their right to set up rules regarding sea turtles and their eggs with the powers conferred to them by the Fisheries Act 1963 and its amendment in 1985 as the animal is constitutionally considered a natural resource that the federated states can decide how best to manage (see Gregory and Sharma, 1997 for the sea turtle legislation scenario within the state-federal division of law in Malaysia). As a result, the sea turtle egg consumption and trade is either totally banned (in Sabah and Sarawak), not at all regulated (in Perlis and Selangor where turtle nesting is insignificant), or regulated through trade concessions (in the remaining nine federated states). Among those in the third category, Terengganu makes the most interesting case study not only due to its place in sea turtle conservation history as the most famous leatherback turtle rookery in the world (Hendrickson and Winterflood, 1961; Chan et al., 1988; Chua and Furtado, 1988) that met a tragic end, but also due to its current importance as one of the major nesting sites for green turtle in the Southeast Asian region (Chan, 2006). Here, conservation efforts on protected nesting areas in Terengganu continue mostly for green turtles through beach monitoring and hatcheries (Chan, 2013; Abd Mutalib et al., 2015). But the trade of sea turtle eggs sourced from legally tendered nesting beaches remains legal and is said to pose a potential threat to the sea turtle population. As much as 422,000 sea turtle eggs were reportedly sold in local markets in 2007 alone (TRAFFIC Southeast Asia, 2009). For this reason, there is much pressure from the sea turtle conservation front to push for stricter legal measures in addition to those that have been put in place by the Terengganu Turtle Enactment (TTE) in 1951 (The Star, 2005; WWF-Malaysia, 2010). The ban on the sale and consumption of sea turtle eggs should, according to scientists and conservationists, be extended to the other three remaining species (Aikanathan and Mortimer, 1990; Chan and Liew, 1996; Chan, 2006; TRAFFIC Southeast Asia, 2009; WWF-Malaysia, 2010), while the tender system must be stopped to avoid the same tragedy with the leatherback turtles (Ibrahim and Sharma, 2006). These anti-concession calls stressed that the legislation of turtle egg exploitation via a tender system jeopardizes the conservation efforts, mainly due to the lucrativeness of the trade (WWFMalaysia, 2012). However, the state has a different view regarding the matter, i.e., such radical action could negatively affect the culture and the livelihood of the people in Terengganu. The state's Chair of Agriculture and Regional Development Council once stated that such a ban would not solve the problem, but could in fact raise market prices and encourage poaching (Kent, 2006). Another representative of the state had confirmed that while the sale or consumption of sea turtle eggs is not encouraged, the state did not plan to ban these practices that are part of Terengganu's tradition (WWF-Malaysia, 2012). Indeed, the sea turtle egg trade not only concerns the turtle's survival but also local community livelihoods. During a media interview, a local trader strongly opposed the idea of banning the trade because it is a source of livelihood, which he did not believe to be a threat to sea turtles' survival (Kuppusamy, 2012). All these proconcession perspectives demonstrate that the complexity of the issues revolving around human-sea turtle interactions in the sea turtle egg trade involves not only the ecological principles but also the cultural, social, economic, and political factors, which have led to an endless debate without any solutions so far in sight. But a better understanding of what actually is already in place from the legal and operational perspectives of sea turtle conservation as well as their reasons why - gained using an approach that appreciates both the value of sea turtle conservation and local livelihoods - will help in finding a constructive next step.

In this paper, the request for "more law" in sea turtle management in Terengganu is considered by examining its policy dimensions based on the Sustainable Livelihoods Approach (SLA). This is primarily because in SLA, the focus has intuitively always been on the "haves" rather than the "have nots" (Bernstein et al., 1992), which the authors consider to be a more practical approach to the debate than the current focus on what is lacking in the state's sea turtle egg trade policy. According to DFID (1999), "a livelihood comprises the capabilities, assets (including both material and social resources) and activities required for a means of living. A livelihood is sustainable when it can cope with and recover from stresses and shocks and maintain or enhance its capabilities and assets both now and in the future, while not undermining the natural resource base" (Section 1.1; see also Scoones, 1998, and Carney, 1998, p. 4). The focus of this paper is on the access component, which consists of elements that mediate the social-institutional and political processes that essentially link resources to strategies that are deployed to achieve the desired livelihood outcomes (Scoones, 2015). By analyzing the 
legal framework of the state's sea turtle management, as well as its actual implementation by state actors, this paper aims to establish what is already in place, on paper and in practice. In presenting explanations of why is it so, this approach allows the authors to review the elements of assets that the various stakeholders have in strategically responding to the Terengganu sea turtle egg trade policy. It then makes it empirically comfortable to consider its efficiency before recommending the way forward, be it more law or not. By doing so, the paper provides an objective insight on the concession versus conservation debate with hope to contribute toward constructive actions to ensure a sustainable future for both local livelihoods and sea turtle populations in Terengganu as well as in other countries where the dialogue on trade bans is taking place.

For answers, the paper engages with relevant documents on the legality of the sea turtle egg trade, and its operation on the ground, and with actors from both sides of the debate, i.e., state officers in charge of sea turtle conservation or trade, past and current trade concessionaires, those involved in harvesting the eggs, and traders who sell them in the market. It begins with a brief description of the study's SLA-based theoretical framework and continues by explaining the research methods. Then, we present and discuss the results from reviewing the existing legal and policy framework for sea turtle management, as well as their actual implementation for providing recommendations toward resolving the trade ban debate.

\section{THEORETICAL FRAMEWORK: SLA-BASED SEA TURTLE POLICY ANALYSIS}

Sustainable livelihoods approach has now developed as a concept and framework (Ashley, 2000; Krantz, 2001) as well as a set of "principles for action" (Toner, 2003, p. 772), and has been applied in designing and reviewing projects, programs, or sectors (Farrington et al., 2004). The strength of livelihoods as a framework lies in its core concepts: firstly to give focus on people, secondly to be holistic in application, and finally to provide the links between the micro, i.e., lived realities of local resource users; and macro, i.e., state level policies and structures; dimensions that are indispensable in resource management (Farrington et al., 2004). According to Murray (2001), its dynamism and the analysis of strengths first rather than needs has provided the framework with many advantages, such as (i) emphasis to understand livelihood diversification in adapting to change in both the present and the past contexts; (ii) advocacy for stretching analysis between different (micro to macro) levels; (iii) acknowledgement of the transboundary nature of different sectors; and finally (iv) recognition given to examining the relationship between the various livelihood strategies within a studied unit and its social interaction with other units of study. Although more widely applied in terrestrial settings, its adoption as the conceptual framework for marine research has allowed for the consideration of both coastal livelihood needs and marine ecological concerns, which are indispensable in livelihoods that are subject to natural resource cycles and fluctuation such as the fisheries sector (Allison and Horemans, 2006). Recently, SLA has also been applied to sea turtle field research to understand the link between community livelihoods, community well-being, and sea turtle conservation where a sea turtle conservation program operates (Montoya and Drews, 2006). The link between "assetaccess-strategies-outcome" in SLA analysis provides a practical research modus operandi in unfolding the often intricate reality of marine endangered species protection and people's livelihood. A broader analytical approach, the use of SLA framework for analysis permits the authors to consider the Terengganu legal institution "as the network of rules and patterns of behavior that condition local resource use and decision making" (King, 2011, p. 299) instead of a mere legal structure and procedures.

This paper is drawn from a study on the human ecology of sea turtle conservation in Terengganu that used this approach to facilitate the process of elucidating the inter-relationships between the livelihood assets, access, strategies, and expectations of resource managers and users. More explicitly, the study examined the various capitals that sea turtle resource managers on one hand and users on the other have, the mediating factors that govern how they apply these capitals into strategic activities, either toward conservation or concession, in order to achieve the outcome that they expect. But this paper focuses primarily on the access component, i.e., the policy on the Terengganu sea turtle egg trade. It looks at the policy framework as an active arena for sea turtle conservation and concession-based livelihood making where there is no tangible "unit of study" such as households or individuals. Instead, this analysis considers the legal "on paper" TTE provisions as the access elements for all those involved in the Terengganu sea turtle egg concession and/or conservation while what is put in practice are "strategies" deployed by these various stakeholders, particularly the Department of Fisheries (DoF), in realizing the outcomes they hope for, i.e., livelihood and sea turtle sustainability (Figure 1). Based on the understandings gained on the available resources, i.e., assets that these actors have, the paper discusses the reasons for their choice. This contributes toward a more holistic evaluation of the current performance of the Terengganu sea turtle management efforts. It therefore begins by analyzing the core of the legal framework, i.e., the provisions in the TTE in its various versions that is the basis for managing sea turtle egg trade and their actual implementation, i.e., the responses of the institutions, organizations, and entities that constitute the active component of the policy dimension in order to later infer on the performance of this legislation.

\section{Qualitative Data Collection}

This paper is based on data collected since November 2014 to May 2018 through various materials and methods. It draws firstly on library and archival materials dated between 1951 and 2018, covering primarily three legal documents, i.e., the TTE in 1951 and its amendments in 1987 and 1989, as well as the tender notice and contract, reports, and minutes of meetings compiled for the Terengganu Turtle Sanctuary Advisory Council (TSAC) from 1988 until 2014, as well as nesting and hatchery management reports and related official documents on the concession or conservation activities (refer to Supplementary Table S1 for the full list). These documents were sourced mainly 


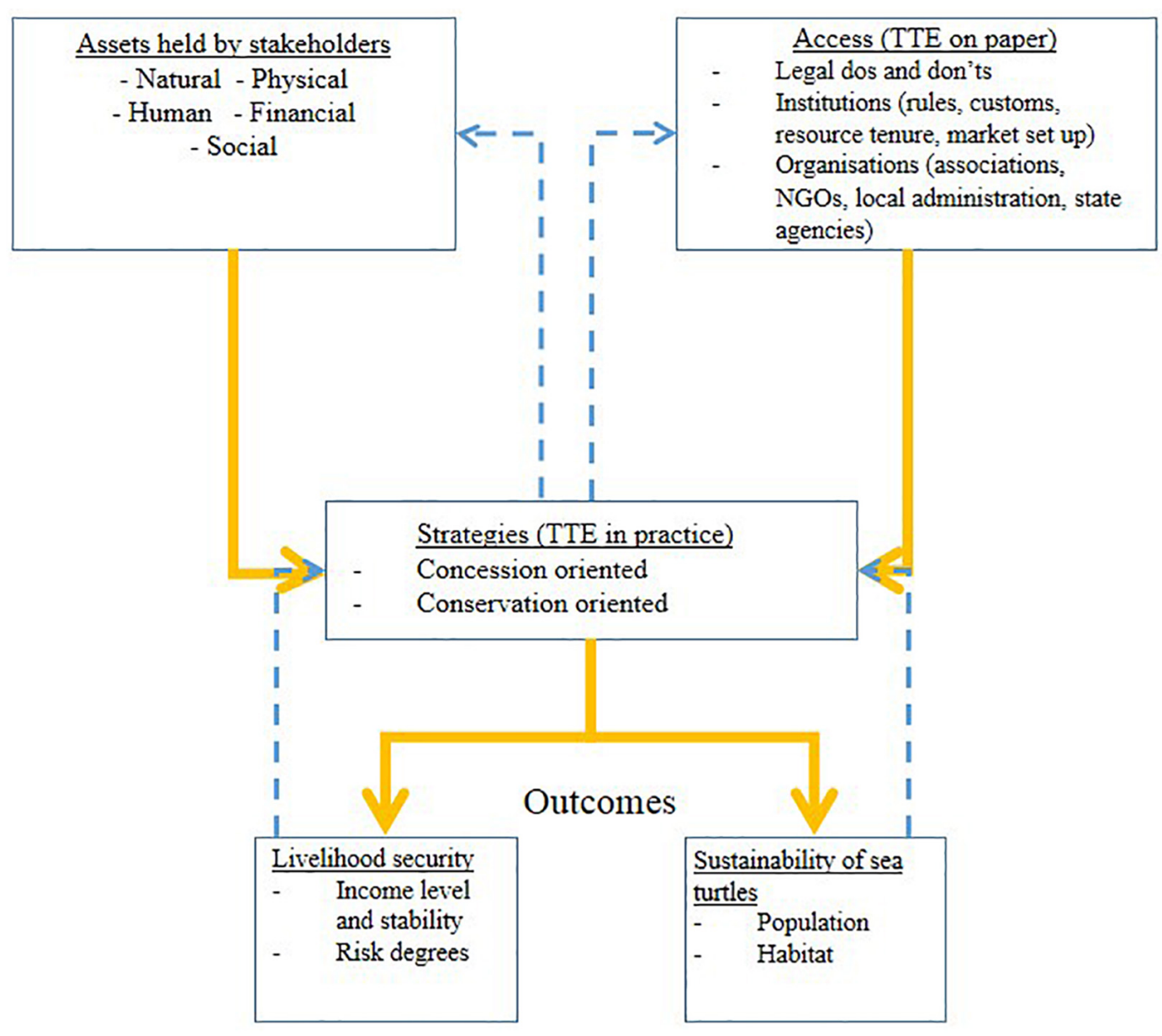

FIGURE 1 | Sustainable livelihoods approach-based theoretical framework for evaluating the Terengganu turtle egg trade policy. Yellow arrows refer to influence while dotted blue arrows refer to response.

from government agencies and NGOs. Literature relating to the legal framework that structures the sea turtle egg concession and conservation in Terengganu since TTE was first introduced was also reviewed.

Secondly, to understand the implementation of sea turtle concession and conservation in reality, the study collected data in the Terengganu mainland and marine park islands by carrying out in-depth qualitative interviews with key informants, i.e., individuals who are directly involved in sea turtle concession and conservation to capture actions and practices of those affected by the legislation. In the mainland where the tender system still exists, the focus was on the practices related to the various activities - from harvesting to retail sale - at licensed beaches and markets as well as reserve and hatchery management. The interviews were conducted from November 2014 until November 2015 with nine sea turtle egg traders based in the main market (Pasar Payang) where most sea turtle eggs are sold, as well as 13 out of 18 registered license holders, of which 6 depended fully on employed egg collectors at their licensed beaches. Three of these employed egg collectors were also interviewed as well as three state government officers. Meanwhile, between October 2016 until April 2018, 70 households were surveyed in the state's main marine park islands of Redang and Perhentian - location of important sea turtle rookeries where the tender system used to exist until 2006 - particularly on the local communities' perception on the impact of the sea turtle nest conservation in these marine protected areas. All respondents were recruited opportunistically, sometimes through snowball sampling due to the sensitivity of the subject. Also included were field notes taken during participant observations in various locations related to the study, from market places to conferences. The data collected were then categorized and later analyzed according to the SLA themes framed by the research framework, i.e., the assetaccess-strategies-outcomes linkages that form the complex policy dimensions between what is legally provided by the TTE and the actual practice (see Figure 1). Specifically, the analysis first concentrates on the access component of the SLA framework, explaining provisions in the TTE for sea turtle concession and conservation. It then reviews the governing and/or institutional structures that are in place and the strategies that are deployed on the ground. Finally, a comparison of what is legally provided 
on paper versus what is actually implemented on the ground is made to identify gaps hampering full protection for sea turtle eggs in Terengganu.

\section{RESULTS}

The results are presented in three subsections. The first subsection shows how the laws have evolved from a purely trade-oriented legislation to one that increasingly became supportive of conservation. The paper then explains in the following subsection that a transition from consumptive to nonconsumptive use of sea turtles has resulted as the stakeholders' strategic adaptation to this legal evolution. Finally, the identified gaps between "paper and practice" - due to the absence of certain governing/institutional structures as well as the lack of certain assets that force those involved to make do with what they have are presented in the third subsection. Through these findings, the outcome that could be expected from the current management of the sea turtle egg trade is then discussed.

\section{TTE on Paper: A Trade Oriented Legislation That Has Evolved in Support of Conservation}

Although there was a provision in the first TTE to create notified areas where no eggs could be taken (no take zone) under Section 8, this state legislation was promulgated in 1951 principally as a legal mechanism to regulate the trade of sea turtle egg. For this reason, the early provision of this law was to enable the establishment of a state governing body of the trade mainly through a licensing mechanism of turtle nesting beaches. It was then a purely trade-oriented legislation that did not cater to any matter beyond managing the allocation of "listed beaches" through concessions earned via commercial tender or exclusive rights. It was, however, considerably amended in 1987 and once again in 1989 to enable the inclusion of a new element of sea turtle management in the state, i.e., turtle sanctuary beaches. Here, eggs nested within the area are fully incubated and the activities allowed within the sanctuary are regulated. Since then, the trade concession of sea turtle eggs, termed concession henceforth in this paper, began to coexist with conservation efforts to protect the same resource. The chronological progress of this transformation is summarized in Figure $\mathbf{2}$ while Table $\mathbf{1}$ presents the different categories of nesting beaches that now exist in the state.

Terengganu turtle enactment is in fact a sophisticated tool for sea turtle conservation for two reasons. Firstly, it has various provisions that, although were originally meant for managing sea turtle egg concession, could also be used for conservation, as summarized in Supplementary Table S2. In general, the law ensures that not everyone has access to egg collection, except in "non-listed areas," i.e., beaches that are neither legally designated for concession nor conservation. Section 7 states that only those with a license, their employees, or the ones given explicit permission to do so are allowed to collect sea turtle eggs at listed beaches for concession or conservation purposes, hence limiting

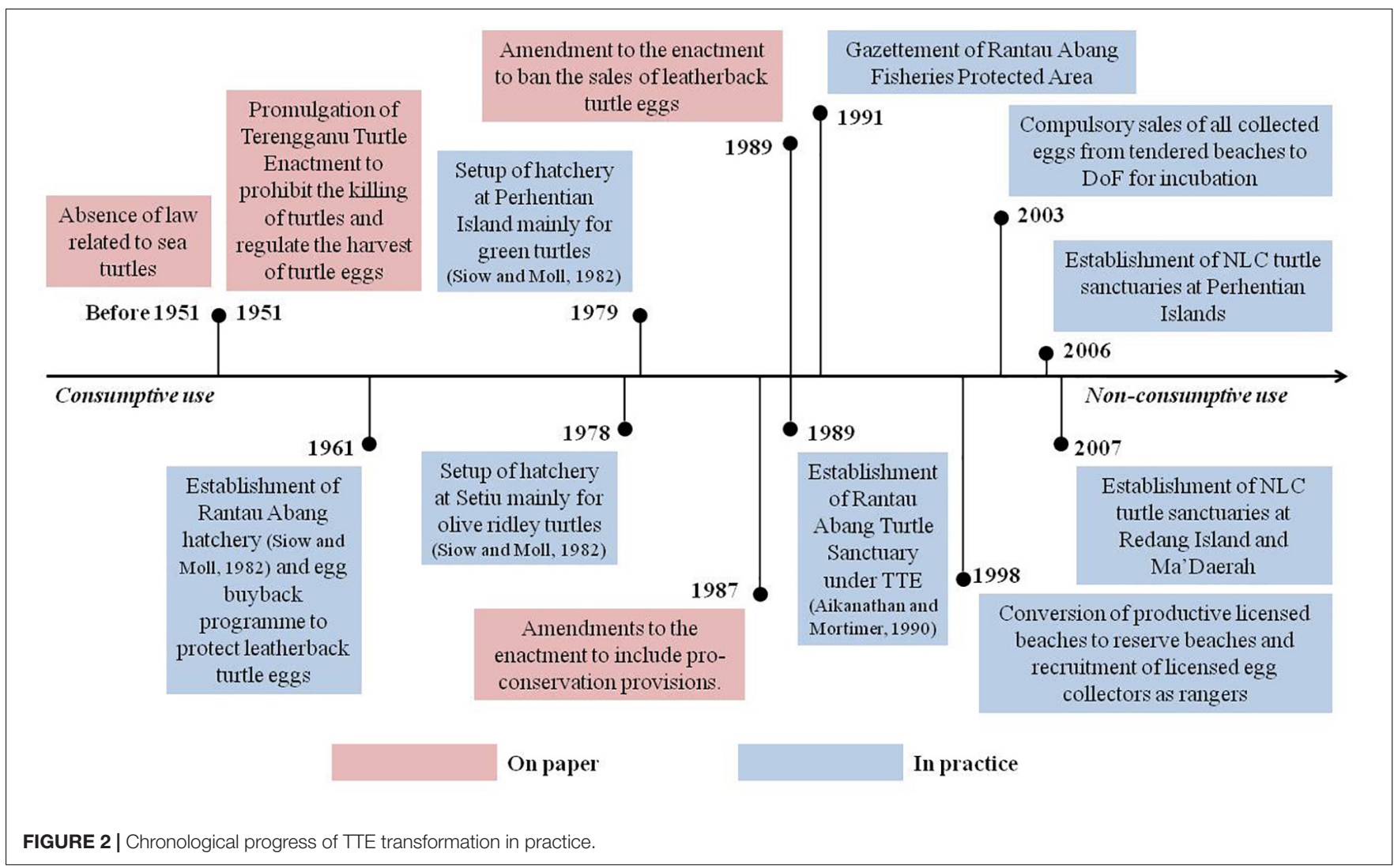


TABLE 1 | Categories of nesting beaches that exist in Terengganu.

\begin{tabular}{|c|c|c|}
\hline Category & Definition & Status \\
\hline $\begin{array}{l}\text { TTE } \\
\text { sanctuary }\end{array}$ & $\begin{array}{l}\text { Nesting beaches that have been gazetted for } \\
\text { conservation as Turtle Sanctuary under Section } 3 A \\
\text { of TTE. }\end{array}$ & LISTED \\
\hline $\begin{array}{l}\text { NLC } \\
\text { sanctuary }\end{array}$ & $\begin{array}{l}\text { Nesting beaches that have been gazetted for } \\
\text { conservation as Turtle Sanctuary under the National } \\
\text { Land Code. }\end{array}$ & LISTED \\
\hline $\begin{array}{l}\text { Notified } \\
\text { areas }\end{array}$ & $\begin{array}{l}\text { Areas designated by the King as no take zones (i.e., for } \\
\text { conservation such as sanctuaries and reserves) under } \\
\text { Section } 8 \text { of TTE. }\end{array}$ & LISTED \\
\hline Licensed & $\begin{array}{l}\text { Nesting beaches that have been listed in the tender list } \\
\text { for egg collection licensing purposes. Although } \\
\text { originally for concession (i.e., trade), eggs from these } \\
\text { beaches could be collected for conservation as well. }\end{array}$ & LISTED \\
\hline Reserve & $\begin{array}{l}\text { Nesting beaches that were formerly listed for tender but } \\
\text { have been delisted and put under DoF's management } \\
\text { for conservation. }\end{array}$ & LISTED \\
\hline No status & $\begin{array}{l}\text { Other beaches in Terengganu that have no official status } \\
\text { under TTE or NLC. Eggs found on these beaches are } \\
\text { not protected and can be collected by anyone. }\end{array}$ & $\begin{array}{l}\text { NON- } \\
\text { LISTED }\end{array}$ \\
\hline
\end{tabular}

access to this resource. Any other person who is suspected to take the eggs in these listed beaches could be taken into custody for investigation and prosecution not only by the Licensing Officer or the Authorized Officer but also a member of the police force. Furthermore, as mentioned earlier, Section 8 makes it possible for the creation of no-take zones in the state for in situ incubation, while Sections 9 and 10 could give license or exclusive right to collect egg for conservation purposes. Other provisions that also benefit conservation are those related to offenses and penalties, i.e., Sections 5, 6, 7, 12, 14, and 15 .

Secondly, it is found that while the enactment has not made any additional amendments to favor sea turtle egg trade, it has done significantly so for conservation since 1987 . In response to the drastic decline of the leatherback turtle population recorded in the 1980s, the 1951 version was extensively adjusted mainly to accommodate a major conservation move, i.e., the establishment of Rantau Abang Turtle Sanctuary under Section 3A in 1987 to make protecting nesting beaches for conservation possible. They resulted in the following three major improvements:

(i) Inclusive management - the addition of Sections 3B, 3C, $3 \mathrm{D}$, and $3 \mathrm{E}$ enabled a more inclusive governance model in the form of the Turtle State Advisory Council (TSAC) whose membership was extended not only to relevant state agents but also the academia and conservation NGOs. Also, the establishment of a local management body via the Turtle Steering Committees at district level was made possible.

(ii) Enhanced enforcement manpower - new provisions under Section 4 created the appointment of various officers and their jurisdiction in enforcement, in particular the Authorized Officer. The section further facilitated the enforcement by the Police where all ranks of the corps could enforce this legislation - not only inspectors and above as stated in the previous version of the law. (iii) Strengthened protection for sea turtles - increased penalties in Section 5 for killing and taking turtles as well as the prohibition of carrying turtle-based tourism activities on any nesting beaches without a license (Section 12A). Finally, in 1989, a total ban on leatherback turtle egg consumption under Section 7A was established - a historical legislation, being the first of its kind in Malaysia and remains a unique legislation because, to date, no other legal ban has been introduced in any of the federated states of Peninsular Malaysia.

Indeed, our findings suggest that in four decades, the TTE has evolved from a mere trade-oriented legislation to one that provides for the implementation of protective measures for the sea turtle population in the state. We found that the evolution of the TTE legislation is progressive due to its receptiveness to scientific reasoning without losing its sensitivity to local traditions, i.e., sea turtle egg consumption. Indeed, based on the reports that were reviewed, the change in the law and in practice appears to have been influenced by the works of sea turtle scientists and conservationists working in the state, who pushed for a top-down move by demonstrating the value of conserving the species. Studies in the 1980s (Siow and Moll, 1982; Mortimer, 1988) contributed toward including provisions for conservation in the enactment that was fully supported from the legal and institutional aspects to ensure the balanced coexistence between concession and conservation of sea turtle eggs. Meanwhile, those in the subsequent decade (see Chan et al., 1985; Chan et al., 1988; Mortimer, 1989, 1990; Aikanathan and Mortimer, 1990; Mortimer and Daud, 1991) successfully pushed the conservation agenda further by influencing the state to use the administrative means provided by the law to move toward a unique proconservation concession system through the introduction of mandatory sale of all collected eggs to the state's DoF. Their engagement with decision-makers at the right moment, such as providing the hard scientific proof of the leatherback turtle's drastic demise, has helped to improve policy making.

\section{TTE in Practice: Transforming Sea Turtles Eggs From a Consumptive to a Non-consumptive Resource}

What has been the impact of this legislation on stakeholders, i.e., agents of the state responsible for managing the concession and conservation of sea turtle eggs, conservation organizations, as well as local communities that depend on the sea turtle eggs for their livelihoods? The chronology of important events that has taken place since its promulgation does suggest that it has firstly been a transformative driver in changing the way that sea turtle is used as a resource - from consumptive to a non-consumptive one, as presented in Figure 2.

It is important to recall that long before TTE was established, sea turtle eggs were traditionally a plentiful subsistence only common resource among coastal villagers in Terengganu. With the advent of modern transportation networks after the Second World War, which improved access to the market that were further away from nesting grounds, sea turtle eggs later became a traded commodity, i.e., for income resource as the egg surplus 
could now be sold for cash. Henceforth, collecting and selling turtle eggs became a new livelihood option for the coastal folks. However, the popularity of this free-for-all trade resulted in disputes that were grave enough to compel a legal intervention from the state, i.e., the TTE establishment in 1951. As a result, sea turtle eggs that were previously a common resource became an "exclusive resource" - one that could only be accessed via commercial tender or special rights. But from the conservation perspective, this had little impact. As explained in the earlier subsection, the initial TTE was a trade-oriented legislation. Thus, all eggs collected then still went to the market, only through fewer hands as people had to earn the state's consent to do so either commercially via concession or politically via special rights. In response, within a decade of TTE, conservationists began setting up hatcheries in Rantau Abang - a sea turtle conservation hotspot due to the massive landing of leatherback turtles - with the support of the DoF that was then officially not part of the legal framework. To get the eggs for incubation, the egg buyback scheme was launched. The same approach was used when hatcheries were set up in late 1970s in Perhentian Island and Setiu, targeted to green and olive ridley turtles, respectively. Indeed, through the egg buyback program, the transformation of this natural consumptive capital into one that is non-consumptive slowly began by encouraging license holders to voluntarily support conservation by selling their collected eggs to hatcheries instead of the market.

The amendments in 1987 and 1989 enabled the setting up of turtle sanctuaries and put an end to the leatherback turtle egg trade, respectively, - further transforming the nature of this resource - at least for one species - from an exclusive resource to one that was no longer accessible. More importantly, it resulted in the appointment of the DoF as the Authorized Officer for the implementation of the conservation elements of the TTE. The DoF has since become the key agent in sea turtle management in Terengganu. The agency also contributed to raising public awareness on the importance of marine conservation in the early 1990 s, in support of the newly established marine park islands in the state that was administered by their Federal counterpart. With increasing awareness raised on sea turtle conservation through the establishment of the Turtle Information Center in Rantau Abang, as well as the increasing popularity of Terengganu's marine protected areas where turtles are given Federal protection, sea turtle eggs became increasingly more popular as a natural heritage to conserve, instead of a natural resource to consume. Equipped with the necessary mandate in hand, DoF introduced more measures to protect important nesting beaches in the late 1990s, through the administrative conversion of more important rookeries into turtle reserve beaches - all selected among the beaches with the highest nesting density and particularly those with operating hatcheries. These reserve beaches are delisted from the tender list, i.e., no longer available for legal tender and became fully managed by the DoF where locally hired rangers (usually selected among egg collectors) are responsible for managing the sites. Administratively created, reserve beaches, however, are not turtle sanctuaries. Therefore, the authority of the DoF rangers is limited to accessing the nested eggs, similar to the license holders' at licensed beaches.
This paper has also found that although not amended since the past three decades, DoF has used TTE's provisions to administratively take the management of this natural resource to go beyond a coexistence between concession and conservation, to currently exist in practice in the form of a pro-conservation legal framework supported by the concession system. Here, "proconservation" refers to a system that is "more supportive toward" instead of "completely in agreement with" conservation motives. This move was achieved by the state DoF via the provision in Section 9 that made the sale of all collected eggs from licensed beaches to DoF for incubation compulsory in the terms and conditions of the tender since 2003. Through this addition, the state further prevented the sea turtle eggs from being traded, hence making a mandatory non-consumptive transformation of the concession system. This means that license holders are in effect working not for the market but for conservation. But such an ambitious move would have a huge financial impact on the state because it would mean repurchasing eggs from 36 nesting beaches. Instead, the agency had strategically delisted the most productive licensed beaches in the state, such as Chagar Hutang in 2005. By 2007, the TSAC has agreed to designate a new status to these most productive beaches as "turtle sanctuary" under the National Land Code (NLC), but not TTE. Meanwhile those that had low nesting record or moderate nesting but difficult to patrol were kept as licensed beaches, i.e., part of the tender list. In other words, DoF's mode of selection between licensed, reserve, or sanctuary beaches appears weighted on the cost implication from the egg buyback scheme: sanctuaries are created only at sites that would incur a significant cost to purchase all eggs due to high-density nesting but are practically easier to patrol, while low-density nesting beaches that are more cost effective to be leased were listed for the tender. Other beaches among licensed beaches that fall in between the two categories (moderate nesting and easy to patrol) were listed as reserve beaches instead. Through this decisive move, the state has done well beyond the suggested conservation target of protecting at least $70 \%$ of the nests (Chan, 2004), as shown in Figure 3.

\section{Transformative Adaptations by Sea Turtle Trade-Dependent Livelihood Makers}

It is important to note that in theory, these transformations through mandatory sale of eggs from licensed beaches as well as converting the most productive among them into NLC sanctuaries or reserves had little, if at all, livelihood implications on those involved in the trade. For egg collectors, the mandatory egg sale had no repercussion on them unless they were also license holders. This is because egg collectors who work as "Ranger Pemajak," i.e., for license holders (livelihood-dependent category) to supplement their low income will still get paid for their effort regardless of the status of the beach. In the case where a beach is converted into a reserve, they will most likely be recruited as rangers by DoF, which is also applicable to license holders who collect eggs on their own. The profiling of these various groups of concession participants that were interviewed as presented in Table 2 provides good insights on this matter. Among the latter, a fraction of them are those who despite their financial hardship secure the tender to maintain access to their family's 


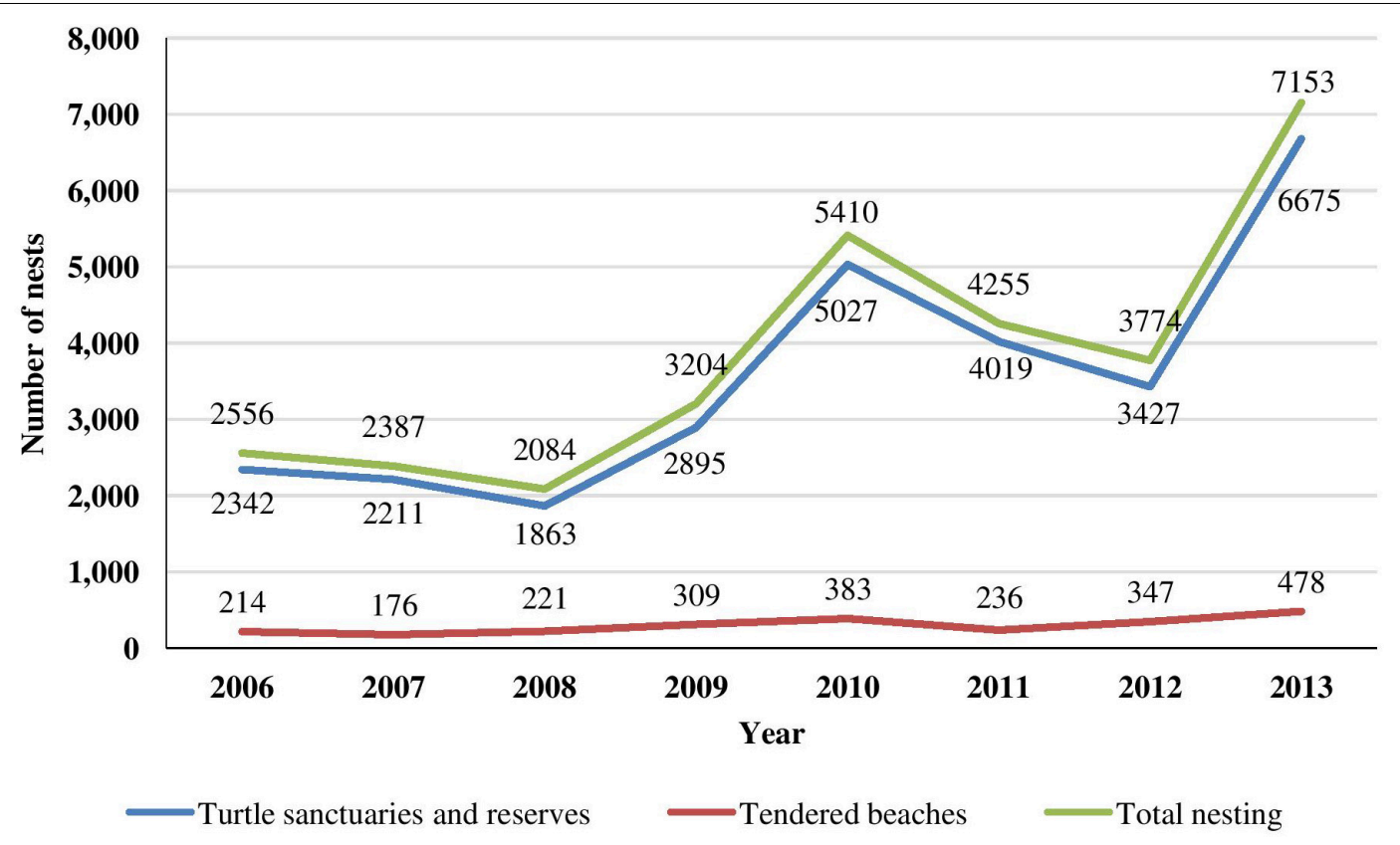

FIGURE 3 | Green turtle nesting record based on beach classification in Terengganu from 2006 until 2013.

"traditional nesting beaches" where sea turtle eggs have been collected for livelihood for generations, hence categorized as livelihood-dependent also. But generally for license holders, there is of course the potential loss of income when fewer beaches became available for tender. On this note, based on the relatively stable nesting number recorded at licensed beaches in stark contrast to the fluctuating trends recorded at turtle reserve and sanctuaries (see Figure 3), it could be suggested that license holders who are legally compelled to report the landing data on their licensed beach may underreport in an attempt to mask its real productivity, to prevent delisting of their licensed beach in the future, as opined three decades ago by Siow and Moll (1982). Losing a beach tender does appear to be a greater cause for concern than the mandatory sale that cuts them off the market trade, which surprisingly did not matter much to most of them as long as they get paid, even for a lower rate than the market. They - termed financially motivated concessionaires explained that there are benefits in selling to hatcheries that outweigh selling to the market, a point to which we return in Egg Buyback Scheme: A Protection Tool With Unfulfilled Potential. The fact that license holders have been encouraged to voluntarily sell their eggs to hatcheries since the 1960s may also have helped to prepare this group for the pro-conservation move when it took effect. Furthermore, most of them hardly depend on the concession for their livelihood, which is already secured via other activities. Peculiarly, however, there are also non-financially motivated concessionaires, who may be the least supportive of the pro-conservation legal framework, due to their consumptive agenda for sea turtle eggs, a point that is also discussed further in Egg Buyback Scheme: A Protection Tool With Unfulfilled Potential. As for the egg sellers in the local markets, the opportunistic, nonexclusive nature of their trade makes them the least dependent on this resource, which they willingly sell when offered to them by those who have the supply, further claiming that they wouldn't if it was prohibited. For the same reason, the delisting of more beaches for protection has little impact on them. It is also found that the move toward non-consumptive use of sea turtles was gaining ground especially with the growth of the tourism industry in Terengganu where sea turtles are an icon. The data collected on the type of livelihood activities among the local communities before and after the conversion of main nesting beaches in the marine park islands of Redang and Perhentian into turtle sanctuaries under the NLC demonstrate this well. Prior to the establishment of these islands as a marine park in 1993, 86\% of the interviewed households depended on fishing activities and egg collection for their livelihoods, whereas the remaining were involved in non-natural-resource-based livelihoods. Now, 44\% of these households are either running a business, self-employed, or being hired in the tourism industry. Meanwhile, 14\% work in conservation as marine park officers or DoF contract rangers, $35 \%$ are in non-natural-resource-based work such as government servants, and only $7 \%$ remain in the fisheries industry.

\section{TTE's Gaps Between Paper and Practice}

Earlier results demonstrated that TTE has provisions that enabled the practical transition toward non-consumptive utilization of sea turtle eggs by those involved in the system in Terengganu, through a legal framework that has evolved from a purely trade-oriented system to one that increasingly grew to support conservation, into becoming a pro-conservation concession system. Over time, the sea turtle eggs that were in the beginning of TTE a purely traded commodity became partially conserved via legislation through the creation of turtle sanctuaries as well as the trade ban of leatherback turtle eggs. Furthermore, it made 
TABLE 2 | Categories of concession participants based on their profile and livelihood dependence.

\begin{tabular}{|c|c|c|}
\hline Category & Profile & $\begin{array}{c}\text { Livelihood } \\
\text { dependence (on } \\
\text { Concession) }\end{array}$ \\
\hline $\begin{array}{l}\text { "Ranger pemajak" } \\
\text { (Employed egg } \\
\text { collectors), } n=3\end{array}$ & $\begin{array}{l}\text { No stable income (coastal fishers) who } \\
\text { work as egg collectors at night to } \\
\text { supplement household income. Some } \\
\text { would bid for the tender if they had the } \\
\text { financial means while others would prefer } \\
\text { working as DoF Ranger for fixed, stable } \\
\text { income. }\end{array}$ & Yes \\
\hline $\begin{array}{l}\text { Traditional } \\
\text { concessionaires, } \\
n=3\end{array}$ & $\begin{array}{l}\text { No stable income (coastal fishers, one } \\
\text { retired) but try hard to raise fund using } \\
\text { saving, loan, or financial aid to secure } \\
\text { tender to keep family's traditional } \\
\text { livelihood practice of collecting eggs. }\end{array}$ & Yes \\
\hline $\begin{array}{l}\text { Business-minded } \\
\text { concessionaires, } \\
n=6\end{array}$ & $\begin{array}{l}\text { Have other stable source(s) of income but } \\
\text { seek to increase wealth though turtle egg } \\
\text { sale. Employ Rangers to patrol and } \\
\text { collect eggs at their licensed beaches. }\end{array}$ & No \\
\hline $\begin{array}{l}\text { Pleasure and } \\
\text { leisure motivated } \\
\text { concessionaires, } \\
n=4\end{array}$ & $\begin{array}{l}\text { Have other stable source(s) of income but } \\
\text { seek exclusive access to nesting beach } \\
\text { and eggs for } \\
\text { (own/family/friends/colleagues) } \\
\text { entertainment and consumption. Employ } \\
\text { Rangers (usually family members) to } \\
\text { patrol and collect eggs at their licensed } \\
\text { beaches or do it themselves. }\end{array}$ & No \\
\hline $\begin{array}{l}\text { Market traders, } \\
n=9\end{array}$ & $\begin{array}{l}\text { Opportunistic sellers (turtle eggs are one } \\
\text { of many other products sold), only when } \\
\text { offered by suppliers (concessionaires, } \\
\text { random local people from Redang). }\end{array}$ & No \\
\hline
\end{tabular}

room for increasingly more conservation measures such as the egg buyback scheme and the status change of nesting beaches to be implemented. The former also involved conservation NGO as egg protection programs had become increasingly more popular since the launch of the first hatchery just a decade after TTE's inception. Through various strategies, both resource managers and users that have either concession or conservation motives have learned to coexist by responding accordingly to these gradual transformations to achieve their respective goals. But our study has also found that not all that was passed by the lawmakers three decades ago were put into practice. In this subsection, we present the important gaps that were found, particularly in relation to the governing institutions, as well as the unfulfilled potential of powerful protective provisions - all linked to the stakeholders' various capital profiles that influence their decisionmaking.

\section{“Who's Who" in Terengganu Sea Turtle Management Scene: The Multitasker, the Helpful Allies, and the Absentees}

Although the law has, on paper, provisions that could resolve most of the major enforcement issues highlighted by scientists and conservationists, our findings suggest that not all provisions were effectively put into practice. Indeed, DoF currently seems to have the most responsibility among all the organizations involved in the management of sea turtles in Terengganu
(Figure 4). The amendments in TTE in 1987 were found to have structured the operationalization of its legal framework under three distinct functions, i.e., conservation, concession, and enforcement. However, DoF has two roles to play, as the Deputy Licensing Officer under Conservation and as an Authorized Officer under Enforcement. Hence, they manage turtle hatcheries and nesting beaches, and collect data and information related to sea turtles in Terengganu, as well as serve as the secretariat of the TSAC that advises the Terengganu State Executive Council on all matters related to turtles. With the pro-conservation concession scheme, there is at least no need for the agency to also take care of all the nesting beaches listed for tender. They only need to buyback collected eggs from these sites, where the responsibility of important tasks such as recording nesting data and patrolling the beaches against poachers is taken up by the license holders.

As for the 18 declared turtle sanctuaries and reserves, DoF currently fully manages 14 beaches and relies on assistance from their allies for the other four. These allies, such as the Sea Turtle Research Unit of Universiti Malaysia Terengganu (SEATRUUMT) and World Wildlife Fund-Malaysia (WWF-Malaysia) that have been helping DoF's conservation work since the 1990s, are not part of the official TTE conservation structure. They are, however, part of the TSAC and have been DoF's most reliable partners, i.e., social capitals in the SLA terminology, that began raising funds to purchase sea turtle eggs at important nesting areas as well as managing hatcheries (see Figure 4 in red). Only when Redang Island and Ma'Daerah beaches were gazetted as turtle sanctuaries under NLC in 2005 were they no longer needed to purchase the eggs to support the hatchery-related conservation work. Before that, SEATRU-UMT had been running the highly productive Chagar Hutang Beach since the 1990s and met their financial needs to purchase the abundant sea turtle eggs and manage their geographically remote project site at Redang Island through novel and innovative fund-raising measures such as "adopt-a-nest" and paid-volunteer programs (Chan, 2013). By the time the beach was converted into an NLC turtle sanctuary, SEATRU-UMT had raised funds to purchase more than 300,000 sea turtle eggs for incubation (Chan, 2004). WWF-Malaysia meanwhile has successfully gained financial support from private corporations as well as through public donations to realize their conservation efforts in the southern and northern nesting sites of the state. Other organizations such as the Lang Tengah Turtle Watch (LTTW) at Lang Tengah Island and Bubbles Dive Resort at Tanjung Tukah Beach, Perhentian Island have also joined in the effort. The former has boldly taken the challenge in competing with commercial license holders to acquire nesting beach tenders, becoming the first "for conservation" license holder since 2014. Meanwhile, Bubbles Dive Resort paid a donation to DoF to acquire a special license to patrol a turtle sanctuary at Perhentian Island.

The above-mentioned conservation allies have become an integral part of the co-management of sea turtles in Terengganu. However, the enforcement for these sites is beyond their jurisdiction as they are not officially authorized enforcers of TTE, except when they also hold a license like LTTW. Therefore, although the earlier discussed findings suggested that there is sufficient law and structure to ensure the effectiveness of TTE 
Terengganu State Executive Council

Turtle Sanctuary Advisory Council

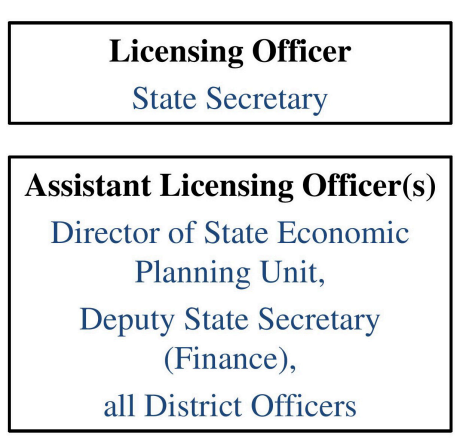

Licensed Egg Collectors

\section{CONCESSION}

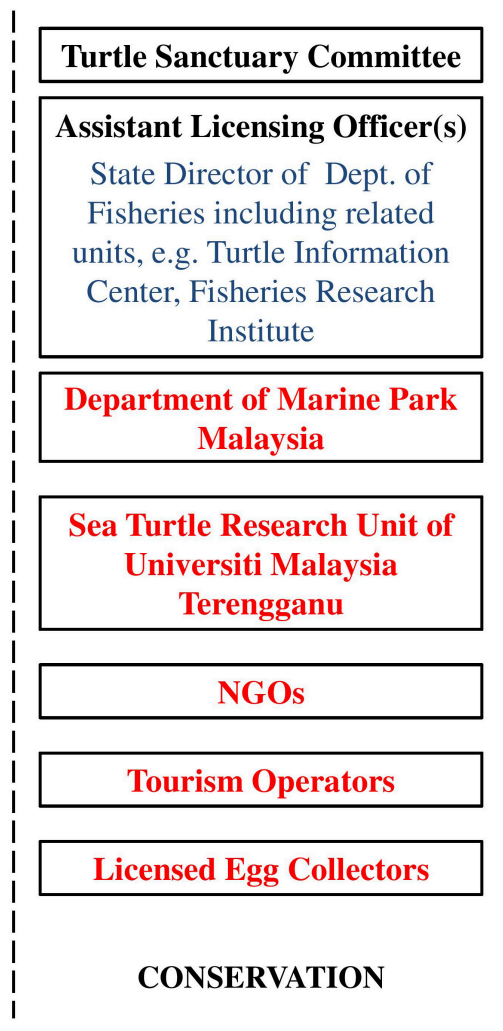

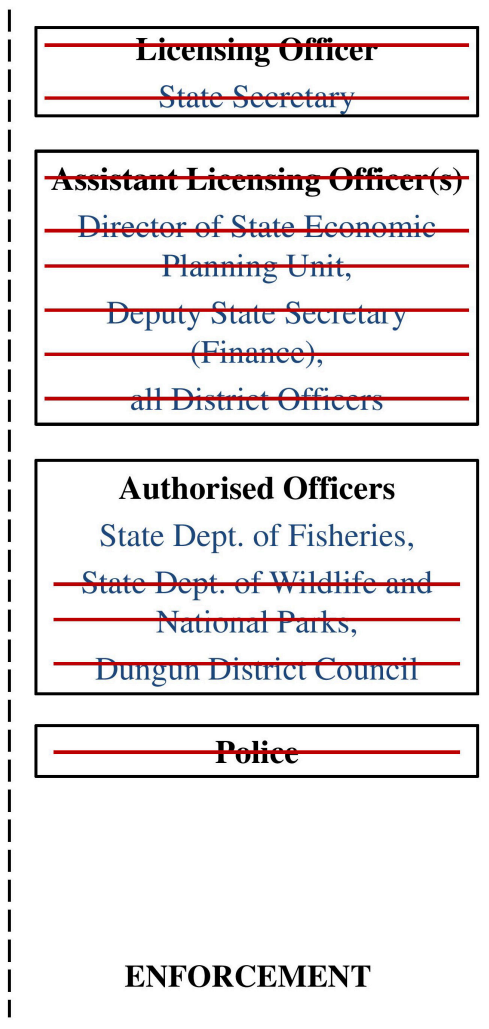

FIGURE 4 | Institutional framework for sea turtle management in Terengganu based on what is practiced in reality, showing the institutions and their appointees (in blue) according to their roles in sea turtle egg concession, conservation, and enforcement. Those crossed in red are structures or agencies that are in reality found absent or not carrying out their roles. Institutions (in red), not provided in the legal institutional, but are added for their role in sea turtle conservation.

where listed beaches are concerned, which would cover all important nesting areas in the state, enforcing the law is indeed a daunting task due to manpower shortage as per the testimony of interviewed DoF officers. However, this human capital deficit would not be as critical if all agencies given the enforcement authority played their roles, and not just the DoF. Institutional absenteeism is instead found: despite extensive provisions given to the Police to carry out enforcement work related to the enactment, there is no documentation of any enforcement activity carried out by them. Similarly, there is no record that the Licensing Officer, i.e., the Terengganu State Secretary, has directly played its enforcement role despite having the legal jurisdiction to do so. The Licensing Officer appears to continue playing their traditional role of managing the concession only.

\section{Egg Buyback Scheme: A Protection Tool With Unfulfilled Potential}

With the establishment of a pro-conservation legal framework via the mandatory egg buyback scheme, the egg concession has become a mechanism for conservation, i.e., a pro-conservation concession system. However, our review on its implementation suggests that its full potential was never fulfilled as it appears that DoF did not buy all the eggs from the licensed beaches. For example, in 2007, 422,000 eggs were estimated to have been traded (TRAFFIC Southeast Asia, 2009), which is almost double the total number of recorded nestings in Terengganu for that year (see Figure 3). Various challenges impede DoF's ability to fulfill its buying obligation, particularly the agency's lack of financial capital to buyback all the eggs. But it does not appear to be an insurmountable challenge as DoF could rely on the help of local NGOs. In 2006, WWF-Malaysia had proactively started to purchase turtle eggs from license holders to increase DoF's incubation rate. In Geliga, 1,300 nests were incubated in 2012 as compared to 300-400 nests prior to 2009 (WWF, 2014). Their participation in the scheme ensured that fewer number of eggs from licensed beaches would end up in the market. When fully implemented, the egg buyback scheme can lead to increased volume of incubated eggs in hatcheries as demonstrated by the data collected from WWF-Malaysia's report in 2014 to the TSAC in Figure 3. However, WWF-Malaysia stopped buying eggs since 2014, potentially resupplying the eggs to the local markets as the license holders who had financial interest in the 
scheme resorted to cover their investment by selling all their eggs commercially instead. The withdrawal of WWF-Malaysia from the scheme in 2014 was a blow to this pro-conservation concession system that no longer could buffer for DoF's human and financial capital shortage.

Besides lack of funds, there are also other challenges in fully implementing the egg buyback system. The license holders had made complaints regarding the DoF bureaucracy in getting their payment after sending their eggs to the hatcheries. However, they admitted at the same time that DoF officers are sympathetic to their administrative woes and always came to their aid in expediting the payment. There were also concerns regarding the extra care that needs to be given to eggs that are transferred to the hatchery for incubation to ensure the survival of the embryo unlike eggs sent to the market that would be consumed anyway. However, under the WWF buyback program, there was an additional financial incentive given to license holder for each successfully hatched egg that compensated for the technical hassle - easily avoided should in situ incubation be practiced. Even so, not all license holders sell their eggs to DoF because the concession also attracts those who seek to personally have exclusive access to egg collection for their own consumption and/or to be given away as rare gifts. This applies to elite license holders including businessmen, government servants, and politicians whose livelihood is not at all dependent on the egg collection, hence irrelevant to the objective of the concession anyway.

Finally, this study found that the local demand for sea turtle eggs remains strong. Interviews with local market traders who all sell them not as a main product but one of many also suggested that the demand remains healthy, even necessitating the smuggling of eggs from Sabah and beyond when there is limited local supply. Apparently, buying turtle eggs at the local markets has also become a tourism activity in Terengganu. According to a state DoF officer, only $10 \%$ of eggs sold in Terengganu are sourced from licensed beaches while the other $90 \%$ are smuggled in from neighboring countries (Sim, 2015). But such demand for eggs need not deter the implementation of the scheme. This is because for these "gourmet" consumers, the eggs are a delicacy and not staple food. Hence, they would accept its market rarity should there be much less supply. As the mandatory sale to DoF is limited to the licensed beaches only, the supply of eggs to meet local demand can be sourced among eggs that could legally be collected from a number of non-listed beaches in the state where turtle nesting does occur, albeit rarely. All the challenges and opportunities mentioned above are presented in Table 3.

\section{Almost but Not Quite TTE Protection for Nesting Sites}

As discussed above, TTE is indeed not a full-proof legislation for sea turtle conservation, not because it allows for concession to exist but because the provision that protects sea turtle eggs from being traded under Section 7 is applicable to listed beaches only. Sea turtle egg incubation statistics (see Figure 3) do suggest that DoF has always maintained the strategy of ensuring at least $80 \%$ of deposited eggs are incubated annually as its main conservation approach - which is well above the $70 \%$ mark
TABLE 3 | Challenges and opportunities in the implementation of the mandatory egg buyback scheme.

\begin{tabular}{|c|c|c|}
\hline Category & Challenges & Opportunities \\
\hline Financial & $\begin{array}{l}\text { DoF has insufficient fund to } \\
\text { purchase all collected eggs } \\
\text { from licensed beaches or } \\
\text { match market price. }\end{array}$ & $\begin{array}{l}\text { License holders prefer to sell to } \\
\text { DoF at even lower price } \\
\text { because DoF in theory would } \\
\text { buy all, while traders only buy } \\
\text { the quantity they need. } \\
\text { Fundraising for egg buyback is } \\
\text { a publicly well-supported } \\
\text { activity that can be supported } \\
\text { by NGOs. }\end{array}$ \\
\hline Administrative & $\begin{array}{l}\text { Claiming payment can be a } \\
\text { hassle for license holders who } \\
\text { do not get paid immediately } \\
\text { while the market pays cash on }\end{array}$ & $\begin{array}{l}\text { DoF is perceived to be quite } \\
\text { understanding of their license } \\
\text { holders' constraints in meeting } \\
\text { documentation needs. }\end{array}$ \\
\hline
\end{tabular}

Technical delivery.

\begin{tabular}{|c|c|}
\hline $\begin{array}{l}\text { Collected eggs must be } \\
\text { handled carefully during } \\
\text { transfer to hatchery (when not } \\
\text { for in situ incubation) to ensure } \\
\text { incubation success, which is } \\
\text { not applicable for }\end{array}$ & $\begin{array}{l}\text { Financial incentive is given to } \\
\text { license holders for each } \\
\text { hatchling recorded, in addition } \\
\text { to the payment for the eggs. } \\
\text { Only applies to ex situ } \\
\text { incubation. }\end{array}$ \\
\hline
\end{tabular}

Personal Some license holders seek to

agenda secure the eggs for own consumption or as rare gifts to be given away (i.e., social capital), so egg buyback will never be an option.

The concession is meant to support turtle egg-dependent local livelihood. This minority group should be excluded from the concession due to their livelihood security.

Market Turtle eggs remain a sought demand after delicacy by locals and are now becoming a new tourism attraction, bought by curious tourists from other states.

A full implementation of egg buyback will not affect non-listed beaches where less frequent nesting occurs. Eggs collected there could be traded, although less abundantly. But as a delicacy, its market rarity will be tolerated.

suggested by scientists (see Limpus, 1993; Chan, 2004). It has successfully done so by protecting all the high-density nesting beaches under various protection schemes (see Table 4), while the less productive ones are either listed for commercial tender or unlisted. However, the more recent sanctuaries were not established under TTE but under NLC. Some of the former are located in the state's marine protected areas, which used to be under the "one island, one tender" approach prior to 2006. Under this scheme, all beaches were listed under a single tender for each island. In 2006, only a few nesting beaches that fulfilled specific criterion - remote, short bays with the most productive nesting record such as Tiga Ruang Beach, Pinang Seribu Beach, Tanjung Tukah Beach, and Tanjung Guntung Beach in Perhentian Island, as well as Chagar Hutang Beach, Che Keling Beach, Bujang Beach, Mak Kepit Beach, and Mak Simpan Beach in Redang Island - were selected as turtle sanctuaries under NLC - a hybrid sea turtle habitat protection scheme. The other beaches, however, became unlisted - not in the tender list nor given any conservation status.

This move was perhaps to make way for the NLC beaches eventual gazettement as sanctuaries under the TTE - the most 
TABLE 4 | List of nesting beaches classified as TTE/NLC turtle sanctuaries or turtle reserves in Terengganu.

\begin{tabular}{|c|c|c|c|}
\hline District & $\begin{array}{l}\text { TTE turtle } \\
\text { sanctuary }\end{array}$ & NLC turtle sanctuary & Turtle reserve \\
\hline Dungun & $\begin{array}{l}\text { Rantau Abang } \\
\text { Beach }\end{array}$ & - & $\begin{array}{l}\text { Rantau Abang } 1 \\
\text { Beach } \\
\text { Rantau Abang } 2 \\
\text { Beach }\end{array}$ \\
\hline Kemaman & - & Ma'Daerah Beach & $\begin{array}{l}\text { Geliga Beach } \\
\text { Rhu Kudung Beach } \\
\text { Chagar Hutan Beach }\end{array}$ \\
\hline Setiu & - & - & $\begin{array}{l}\text { Telaga Papan } 1 \text { Beach } \\
\text { Telaga Papan } 2 \text { Beach } \\
\text { Kuala Bharu Selatan } \\
\text { Beach }\end{array}$ \\
\hline Besut & - & $\begin{array}{l}\text { Perhentian Islands: } \\
\text { Pinang Seribu Beach; } \\
\text { Tiga Ruang Beach; } \\
\text { Tanjung Tukah Beach; } \\
\text { Tiga Ruang } 2 \text { Beach; } \\
\text { Tanjung Guntung Beach }\end{array}$ & - \\
\hline Kuala Terengganu & $1-$ & $\begin{array}{l}\text { Redang Island: } \\
\text { Chagar Hutang Beach; } \\
\text { Mak Kepit Beach, } \\
\text { Bujang Beach, Mak } \\
\text { Simpan Beach; } \\
\text { Che Keling Beach }\end{array}$ & \\
\hline
\end{tabular}

comprehensive protection status that puts everything from land development to turtle nesting matters under the same jurisdiction. Under TTE, the turtle sanctuary beach land is protected exclusively for turtle nesting, where no egg collection is allowed and the area is out of bounds for the public during certain hours to ensure optimal condition for nesting turtles. However, this has yet to happen after more than a decade and Rantau Abang remains the only TTE turtle sanctuary since 1989. As for these other "hybrid" sanctuaries, although gazetted under NLC as turtle sanctuaries, they are only protected from development by the District Office and do not necessarily have access to the protective provisions under TTE unless officially declared as listed for conservation by its authority. While their land matters legally fall directly under the District Officer, matters related to turtle nesting are assumed by various organizations, i.e., SEATRUUMT in Chagar Hutang, WWF-Malaysia in Ma'Daerah, and DoF in the rest. Meanwhile, turtle reserves, the third type of listed beaches, are managed by DoF, whose presence on site provides a protection as sound as TTE sanctuaries, although they technically are no different than licensed beaches, except that DoF is the operator instead of a license holder. Fortunately, the ambiguous status of NLC turtle sanctuaries and DoF-operated turtle reserves never seemed to be questioned, enabling total conservation. But, eggs from the rest of the beaches in these marine park islands now all unlisted - could end up being traded in the markets. Furthermore, the local sea turtle egg traders openly list the exotic (MPA) origin of their Redang sourced goods - much to the consternation of conservationist.

\section{Other Issue: Terengganu as a Turtle Egg Trading Hub}

Besides the presence of "Redang" eggs in the local markets, there are also those that presumably hail from other states, particularly Sabah where a total trade ban has been declared. This is because TTE does not prevent eggs sourced from other states and countries from being traded in Terengganu. This strikes another blow to Terengganu's conservation image, denounced as a hub for illegally sourced eggs from another state and neighboring countries (The Star, 2006, 2010, 2015; Sim, 2015). The local traders claim to be not inclined to market them with a "Terengganu" label to avoid ruining one's reputation by selling these externally sourced eggs as local eggs due to their reportedly inferior quality compared to the locally sourced ones, which local consumers apparently can easily detect and prefer to avoid. These eggs are usually bought by less knowledgeable, curious tourists from other states in Malaysia or foreigners instead, some of whom purposely seek the eggs at the local market.

\section{DISCUSSION}

By examining the conditions and consequences of the Terengganu sea turtle legal framework, the paper revealed the interdependencies between the access component (what policy is put in place) with those of stakeholders' strategies (what they do in response to the policy) using their available assets (the various resources that they have), which resulted in the current conservation and livelihood outcomes. The findings made by reading the enactment carefully do imply that in theory, there are provisions to ensure that conservation thrives in the state despite its coexistence with the sea turtle egg concession. This is because what has been legally put in place in this pro-conservation legal framework is in fact a concession system where even the commercial egg collectors now work for conservation. This scheme is unlike the withdrawal right given to the local communities in Ostional, Costa Rica to collect the eggs as prescribed by the law during the mass synchronized sea turtle nesting called "arribadas" for trade or own consumption (Campbell, 2007), which is more comparable to the case studied in Venezuela by Barrios-Garrido et al. (2017). Instead, it is quite a unique model because in Terengganu's case, the Licensing Officers used their management rights to reroute the eggs away from the market to the hatcheries. Some, however, would argue that the "commodification" of the eggs, i.e., payment to the license holders for the eggs, makes it unworthy for conservation because it is "philosophically suspect" (Ferraro, 2007: 32). It conflicted WWF-Malaysia's policy (Zolkepli, 2012), which, although acknowledged the Malaysian egg buyback program as a success, alleged that it "still puts a commercial value on turtle eggs instead of a conservation value" (WWF, 2014:11). Often, moral, instead of biological, reasoning does lead sea turtle experts and conservationists to denounce any legal exception to a trade ban even when it improves support for local conservation (Campbell, 2007). The repeated calls for TTE to include a total ban on all sea turtle egg trade as the recommended solution for weaknesses found in the management of the species (Bernama, 2006; 
TRAFFIC Southeast Asia, 2009; WWF-Malaysia, 2012, 2018; Zolkepli, 2012) are no different, recommending the moratorium to change local consumptive behavior. Their concerns are indeed valid as Terengganu - synonymous with sea turtles since the heydays of leatherback turtle landings in Rantau Abang - must learn the important lessons from the trade ban on leatherback turtle eggs in 1989 that had, however, come too late, and failed to avoid the extinction of the species (Liew, 2011). For this reason, sea turtle conservation is a matter of concern in Terengganu as well as in the Southeast Asian region. Hence, the labeling of this scheme as pro-conservation may indeed face fierce criticism as TTE does not currently cover all beaches in the state, only listed ones where nesting density is substantial. Therefore, there is still open access to local sea turtle eggs found and collected at random beaches that may still potentially end up in the market, traded among extra-Terengganu eggs as explained earlier. But there is perhaps wisdom in this approach of compromise. After surveying the various traditional consumptive uses of sea turtles in Southwestern Africa, Fretey et al. (2007) cautioned that conservationist must respect local traditional use - including consumptive in nature - if they wish to save sea turtles because in such localities, legal prohibition imposed in the name of species conservation alone rarely works. It is a reality corroborated by IOSEA's 2014 report on the unlawful use of turtle parts in $75 \%$ of its member countries. Therefore, scientists and conservationists, often the privileged rather than marginalized group in policymaking (Guha, 2003), must reflect on the political correctness of their motivations in overriding local mores in the name of sea turtles. Demands are now being made (Rudrud, 2010) or defended (Barrios-Garrido et al., 2017) by indigenous peoples on their customary rights to consume sea turtles, and in places where human consumption has long been part of traditional but effective local ecosystem management strategies, turning a deaf ear is nothing more than an emotional, evasive stand. But Campbell (2007) has shown that heeding local claims to consumptive use is perhaps counterintuitive among "for turtle" folks. Her work in Costa Rica has shown how some turtle conservationists have resorted to using more serious regional or global endangered status to defend or push local conservation agenda, although the local population of the species is actually not in grave danger. This is why this paper maintains that TTE in its current form is unique because it has shown an ingenuity of seeking balance between the often conflicting priorities of local people and conservationists. It exemplifies a management strategy that is scientifically guided without losing its intuitions for local traditions and practices. Originally established in 1951 exclusively for trade regulation, it has gradually become a policy that is in fact biased toward protection, i.e., pro-conservation. Over time, TTE has what it takes to make it possible to achieve the desired outcomes of sustaining the Terengganu sea turtle populations and turtle-egg-dependent local livelihoods should all the legal provisions be optimally put to use in practice.

The results do show that this unique pro-conservation legal system has been the driver for a progressive shift from consumptive, i.e., for concession, to non-consumptive, i.e., for conservation, utilization of sea turtles as a resource through various strategies that the multiple actors in the policy realm of sea turtle management have put into practice toward gaining the best outcome they could expect with the resources that they have at their disposal. But as highlighted in the section TTE's Gaps Between Paper and Practice, there are gaps in its implementation. Nonetheless, the current management strategies carried out are a result of maximizing strengths in certain capitals for compensating limitations in others in order to achieve a balanced outcome between supporting the livelihood of those dependent on the trade and the sustainability of sea turtle population. The DoF has therefore enhanced the use of the egg buyback scheme as an effective management tool by embedding the potential cost of egg buyback in their selection criteria for licensed beaches. For this reason, the paper differs in opinion with views that the egg buyback scheme should not be encouraged (Kent, 2006; The Star, 2011). It argues that the egg buyback scheme is a perfect companion to the conservation approach currently taken in Terengganu because it effectively helps DoF to cope with the human capital constraints that it faces through the optimal use of the same capital that the license holders readily have access to: egg collectors who are able bodied and possess valuable local ecological knowledge on sea turtle nesting behavior. The former, due to the long tradition and practice of egg harvesting in the state, are highly knowledgeable and skilled in finding sea turtle nests and are in fact the real experts in the field (TRAFFIC Southeast Asia, 2009). They, however, may not all want to be employed as rangers due to the seasonal nature of the occupation and low wage, which is just one of the many livelihood strategies that the coastal communities employ to achieve their desired livelihood outcomes. Therefore, ideally, the concession system provides a way to protect more nesting beaches with a limited budget, e.g., reducing the cost by buying eggs instead of paying for seasonal rangers in low-density nesting sites. Indeed, in many places where sea turtle conservation has livelihood implication, using such economic incentives, although philosophically troubling to conservationists, is the most effective way to ensure that conservation goals are met (Ferraro and Gjertsen, 2009). Moreover, in a true display of livelihood resilience, the local communities at the marine park islands that formerly used to co-own the tender through cooperatives have now ventured into tourism operations, where sea turtlerelated tourism (i.e., turtle watching in the water) is now the most popular attraction, similar to the leatherbacks in the past. The spill-over effect from sea turtle tourism is enjoyed by local traders whose various turtle inspired merchandises are coveted by tourists and locals alike. Hence, sea turtles are reclaimed as a natural capital by the Terengganu people, in this context more valuable alive than consumed, which is similar to Tortuguero where turtle tourism has become a major source of revenue to the local communities (Place, 1991). This option, recommended by conservationists (Sardeshpande and MacMillan, 2019), must, however, be thoroughly evaluated and strategically incorporated into the legal framework to avoid abuses. But in sum, we opine that the current management of sea turtles in Terengganu is a resilient "making do" model of compromise that would still result in (i) the protection of the most important nesting sites to ensure the incubation of at least $70 \%$ of the nests in sustaining the local sea turtle 
population while (ii) sustaining egg-collection-dependent local community livelihood via employment at reserve beaches and sanctuaries as conservation rangers or at licensed beaches as commercial egg collectors.

But is this outcome - one that results from maintaining the status quo, i.e., a quasi-practiced pro conservation legal framework - enough? To this, our short answer is yes, if the state of Terengganu is set to only maintain the population via incubation of at least $70 \%$ of the nests as recommended by scientists. However, it must be willing to face continued criticism for not committing to a legal condition that it has introduced, i.e., the egg buyback scheme, as well as for not doing enough enforcement, thus allowing Terengganu to become a sea turtle egg trading hub in the region (The Star, 2015; WWF-Malaysia, 2018). Our findings on the existing discrepancy between paper and practice have shown that more could already be achieved by doing a little more, i.e., implementing the proconservation concession system in full without even making any change to the law. The non-optimization of the law must be understood as the root cause for the setbacks against achieving the current management goal of the sea turtle egg trade, and not the lack of law. We do therefore opine that it is crucial to immediately address the challenging issues that hamper the fulfilment of TTE's full potential. After all, legislation is naught without effective implementation (Koch et al., 2006; Mancini et al., 2011). Hence, there would be no point to consider more law to protect sea turtles in the state if maximum effort was never given to fully put the existing one to optimal use. To begin with, the "institutional absenteeism," which we highlighted in the section "Who's Who" in Terengganu Sea Turtle Management Scene: The Multitasker, the Helpful Allies, and the Absentees, could be immediately remedied by increasing the presence of enforcement through the active participation of the police force. Their absenteeism compromises the optimal operationalization of this important function because poaching becomes a serious problem when enforcement is perceived to be slack (Keane et al., 2008). Simply due to their omnipresence and their status as a publicly recognized enforcement authority, members of the police corps would positively impact the lawfulness of those involved in not only the trade but all activities related to sea turtles including conservation and tourism in accordance to TTE legal provisions without increasing the number of DoF personnel. The Licensing Officer could also involve other well-meaning, local individuals or groups with proven good record such as MEKAR and PEWANIS - community-based conservation groups set up with the help of WWF Malaysia - by issuing special permits to help with enforcement at nesting beaches, from simple patrolling to even investigations at specific listed beaches. This would help increase the local communities' role in co-managing sea turtles, which Shyuji (2015) found was lacking.

Although the egg buyback scheme would have ensured the total incubation of all sea turtle eggs from licensed beaches, DoF, in our opinion, was perhaps never able to fully commit to it due to the colossal financial implication it would incur. Having largely achieved the "conservation quota" as discussed earlier in the section TTE in Practice: Transforming Sea Turtles Eggs From a Consumptive to a Non-consumptive Resource through the sanctuaries and reserves, the balance sold to the market is perhaps deemed insignificant. However, the mandatory contractual condition has been pragmatically maintained to this day, presumably as a useful backup strategy that can be used when nesting rates are low, requiring the acquisition of sea turtle eggs from the licensed beaches to ensure meeting the said target. But when not purchased for conservation, a gray market for the non-purchased eggs is created, where although illegal in theory, DoF would not be in the moral, if not legal, position to take action against their sale as the agency has not fulfilled its end of the contract. This is the reason why all the enabling factors for a fully implemented pro-conservation concession scheme, i.e., the opportunities presented in Table 3 that could address the challenges in implementing the egg buyback scheme, must be put to good use. This means that the state must increase their support to enable DoF to buyback all the nests from license holders, perhaps resorting to crowd funding mechanisms with the help of NGOs. In doing so, the access to trade will also be limited to almost null because eggs from all licensed beaches - i.e., nesting beaches identified for tender - will now be incubated as those from turtle sanctuaries or reserves. Meanwhile, the conservation activities such as recording and reporting nesting data as well as preventing poaching through beach patrolling that would have to be carried out by DoF will be assured by the license holders. As argued by Ferraro and Gjertsen (2009) based on a global review of incentives for sea turtle conservation, the egg buyback is the most economically cost effective and possibly most locally favored solution for sea turtle conservation when local harvesting is legally regulated. If all eggs from licensed beaches are bought back for conservation, there will only be those from non-listed beaches, a potentially insignificant amount. Other issues related to the egg buyback scheme must also be taken care of: simplified claim procedure could be introduced to facilitate repayment to license holders while good incentives such as the hatchling bonus should be maintained; more in situ incubation to reduce transfer hassle and increase incubation success; the bidding open only to real "professionals," i.e. those with nonconsumptive (for financial or conservation gain) motives only, while those with consumptive agenda can join members of the public in purchasing legal eggs - sourced from non-listed beaches in the state or beyond - at the local markets. With these optimization measures, the outcome could be (i) better enforcement capabilities by DoF due to the increased human capital that can now fully play their role with a free conscience, having now fulfilled their end of the tender contract; and (ii) total absence of eggs from listed beaches at local markets.

The fully implemented pro-conservation legal framework offers, in our opinion, a better management outcome than the former. But it still means that some eggs nested in Terengganu can end up in the market - not yet an acceptable outcome in the eyes of some who wish to see the end of the trade. Indeed, the state could upgrade the current pro-conservation legal framework to a full-conservation concession system, i.e., the TSAC can, using the administrative means provided in Section 9, include all beaches that are currently not listed as turtle sanctuaries or reserves in the state as licensed beaches from where all the eggs collected would be incubated as well due to the mandatory sale condition 
of the tender contract. However, DoF must be provided with sufficient financial support to buy all the eggs collected by license holders. To the authors of the paper, this is the preferred option at the moment for Terengganu should the state seek to conserve all locally nested eggs without disrupting the balance between livelihood and conservation. It is reiterated that the egg buyback scheme does not encourage trade but serves only as a buffer for turtle egg-dependent livelihood, as well as creating a costeffective alternative management solution for nesting beaches. Meanwhile any egg collected from the non-bidden locations will still be legally protected and could not be harvested without the concession. This facilitates enforcement work as action can be taken on anyone else found to have sea turtle eggs in their possession because this administrative measure ensures that no Terengganu sea turtle egg should end up in the market, and those that do can be confiscated. This immediately allows taking action on the local eggs such as those contentious "Redang" eggs.

However, under this full conservation legal framework, nothing could still be done to eggs proven to hail from other Malaysian states, creating a nagging concern of the state becoming a trade hub for "extra-Terengganu" turtle eggs. Therefore, even the full conservation type of concession in Terengganu does not prevent the state from becoming a trade hub as only Terengganu eggs are prohibited from the market, but not those sourced outside of Terengganu. Despite a total ban in Sabah, illegal trade does take place discreetly in local markets, and high state officials have been caught red-handed for sea turtle egg fine-dining (Today Online, 2015). A huge quantity of "Sabah" labeled eggs end up sold in Terengganu, at a lower price than the local sea turtle eggs, as they arrive less fresh and have to usually be pickled, having traveled across the South China Sea to get to Terengganu (WWF-Malaysia, 2018). This is an important lesson to note, because the trade shall persist for as long as there is a demand (TRAFFIC Southeast Asia, 2009), which our findings have shown to be strong among the local population in Terengganu. It is also not impossible that these "Sabah" eggs do hail from foreign origins - but are being imported via Sabah (WWF-Malaysia, 2018), and labeled as such due to CITES. Indeed, while importing sea turtle eggs from any foreign country is illegal, there is no prohibition against selling eggs from Sabah elsewhere in Malaysia where the trade is legal. Perhaps a local version of CITES may be considered as a possible solution to this problem. Indeed, if the "Sabah" sea turtle eggs could be confiscated, a huge amount would disappear from the local markets. The origin of local sea turtle eggs supply could be verified through investigation by the local enforcement team, which would become better capacitated to do so with the full participation of all TTE nominated enforcement agencies as discussed earlier. Of course, the other solution to stop extraTerengganu eggs that could also be taken is for the state to move toward amending the law - the first in almost 30 years - to impose a sea turtle egg trade moratorium on all species. This would turn TTE into a total conservation legal framework.

Indeed, the current conservation efforts in Terengganu, which include protecting turtle sanctuaries at nesting beaches and offshore habitats as well as providing education to increase knowledge and public awareness, may not be sufficient in sustaining a viable turtle population, considering the increased threats to the survival of this migratory species at various life history stages (Klein et al., 2017). It therefore may seem that since the egg buyback scheme is not sustainable without funding, a ban on the commercial sale and trade of sea turtle eggs may discourage their trade and increase the number of eggs incubated in the hatchery. But the paper affirms that a moratorium of the trade now may not likely solve the problem, as proven by the transgressions that have been recorded in Sabah (Sario, 2016; Kasmir, 2017). DoF is surely aware of the implementation challenges that a trade ban will have without popular public support. Indeed, sea turtle conservationists in Terengganu must gain a better understanding on the consumptive value of sea turtle among the local community before pushing for increased protective measures such as a total trade ban. It is also worth noting that when harvesting has always been part of the nesting equation, its absence could also be detrimental to the local sea turtle nesting population. Ferraro and Gjertsen (2009) reported how a total ban in an important but isolated rookery in Kalimantan resulted in more nest loss due to predation by rats that had flourished since the egg collectors ceased to visit the beach. On the contrary, their presence could help conservation work in the long run. Campbell et al. (2007) also noted that since the legalization of harvesting during arribadas in Ostional (Costa Rica), illegal harvesting has become less accepted by the local community, and better infrastructure has been provided by the community themselves to help patrolling activities. Furthermore, total conservation may even lead to sea turtle overpopulation that has been found to be damaging to local marine ecosystems (Lal et al., 2010).

\section{CONCLUSION}

By adopting the SLA approach, this study has found that while the TTE may not impose a trade moratorium yet, it still has powerful elements that are necessary in making sea turtle conservation a success since its transformation from a concession-oriented legislation in the 1950 s to one that is proconservation in practice in the recent years. This shift has indeed made sea turtle conservation the state's priority over trade and enabled the incubation of enough sea turtle eggs for ensuring the sustainability of the sea turtles in the state as well as protecting genuine turtle-dependent livelihood. However, should turtle egg trade moratorium be the desired outcome for Terengganu, then the total conservation legal framework via trade ban will need to be supported by interstate legal mechanism as well, to ensure that the eggs will not simply end up being exported to other Malaysian states such as Kelantan and Pahang where demand also exists. It is therefore important to emphasize that this paper is not against imposing a law to ban the trade of sea turtle eggs, which should indisputably be the ultimate outcome in sea turtle conservation in Terengganu. However, legislative reviews take time, much more than administrative amendments such as the one that concerns the listed beaches. Furthermore, as discussed above, the full potential of the existing law that was diligently put in place with scientific insights and local sensitivity by lawmakers almost three 
decades ago has not yet even been reached. It may therefore be more productive and realistic to now concentrate on optimizing what are already in place instead of asking for even more law that may only create new enforcement challenges in addition to those already discussed above. Limited enforcement capabilities coupled with strong local demand for egg consumption due to low conservation awareness will backfire against such a ban. Hence, efforts must be made in solving the problems related to the access to sea turtle conservation as discussed above to ensure the sustainability of both sea turtles and local livelihoods in the state's current legislation system. By turning it first into a full conservation legal framework, the state will pave the way for a total conservation legal framework via a total trade ban - to be implemented when all is ready to make a moratorium fully work.

\section{ETHICS STATEMENT}

This study was carried out in accordance with the recommendations of UMT Field Research Guideline, UMT Research Management Centre with written informed consent from all subjects. All subjects gave written informed consent in accordance with the Declaration of Helsinki. The protocol was approved by the UMT Research Management Centre.

\section{AUTHOR CONTRIBUTIONS}

JM, MJ, and SL contributed in gathering and analyzing the data, interpreting the results, producing the figures and tables, and writing the manuscript.

\section{REFERENCES}

Abd Mutalib, A. H., Fadzly, N., Ahmad, A., and Nasir, N. (2015). Understanding nesting ecology and behaviour of green marine turtles at Setiu. Terengganu, Malaysia. Mar. Ecol. 36, 1003-1012. doi: 10.1111/maec.12197

Aikanathan, S., and Mortimer, J. A. (1990). Recommendations for the Establishment and Management of Turtle Sanctuaries and Hatcheries in the State of Terengganu: a Report Submitted to the Turtles Sanctuary Advisory Council of Terengganu. Selangor: WWF-Malaysia.

Allison, E. H., and Horemans, B. (2006). Putting the principles of the Sustainable Livelihoods Approach into fisheries development policy and practice. Mar. Policy 30, 757-766. doi: 10.1016/j.marpol.2006.02.001

Ashley, C. (2000). "Applying livelihood approaches to natural resource management initiatives: experiences in namibia and kenya," ODI Working Paper 134, (London: Chameleon Press).

Barrios-Garrido, H., Espinoza-Rodríguez, N., Rojas-Cañizales, D., Palmar, J., Wildermann, N., Montiel-Villalobos, M. G., et al. (2017). Trade of marine turtles along the Southwestern Coast of the Gulf of Venezuela. Mar. Biodivers. $\operatorname{Rec} 10: 15$. doi: 10.1186/s41200-017-0115-0

Bernama (2006). "Scientist Wants Ban on Sale of Leatherback Turtle Eggs." Wild Singapore, 29 September, 2006. Available at: http://www.wildsingapore.com/ news/20060910/060925-4.htm (accessed February 14, 2019).

Bernstein, H., Crow, B., and Johnson, H. (1992). Rural Livelihoods: Crises and Responses. London: Oxford University Press.

Campbell, L. M. (2002). Science and sustainable use: views of marine turtle conservation experts. Ecol. Appl. 12, 1229-1246. doi: 10.1890/1051-0761(2002) 012\%5B1229:sasuvo\%5D2.0.co;2

Campbell, L. M. (2007). Local conservation practice and global discourse: a political ecology of sea turtle conservation. Ann. Am. Assoc. Geog. 97, 313-334. doi: 10.1111/j.1467-8306.2007.00538.x

\section{FUNDING}

This work was mainly based on a research project financed by the Malaysian Ministry of Education through its Research Acculturation Collaborative Effort (RACE) Scheme (Project VoT No. 56028), as well as the initial support provided through the same ministry's HICOE grant distributed via the Institute of Oceanography and Environment (INOS), Universiti Malaysia Terengganu.

\section{ACKNOWLEDGMENTS}

We would like to thank the officers of the Department of Fisheries (DoF) and the Terengganu State Secretary Office who assisted during the archival research and as research respondents. Other members of the latter group, from egg collectors to traders and restaurant owners, as well as Redang and Perhentian Islands communities are also duly acknowledged for their valuable contribution to the research. We wish to dedicate this article to the late Abdul Hadi Harman Shah, the RACE project mentor who lost his battle against cancer in 2015.

\section{SUPPLEMENTARY MATERIAL}

The Supplementary Material for this article can be found online at: https://www.frontiersin.org/articles/10.3389/fmars. 2019.00762/full\#supplementary-material

Campbell, L. M. (2010). Studying sea turtle conservation and learning about the world: insights from social science. Conserv. Soc. 8, 1-4. doi: 10.4103/09724923.62671

Campbell, L. M., Haalboom, B. J., and Trow, J. (2007). Sustainability of community-based conservation: sea turtle egg harvesting in Ostional (Costa Rica) ten years later. Environ. Conserv. 34, 122-131. doi: 10.1017/S03768 92907003840

Carney, D. (1998). Sustainable Rural Livelihoods: What Contributions Can We Make? London: DFID.

Chan, E. H. (2004). Turtles in trouble. Siri Syarahan Inaugurul KUSTEM: 7 (2004). Trengganu: Kustem

Chan, E. H. (2006). Marine turtles in Malaysia: On the verge of extinction? Aquat. Ecosyst. Health 9, 175-184. doi: 10.1080/14634980600701559

Chan, E. H. (2013). A report on the first 16 years of a long-term marine turtle conservation project in Malaysia. Asian J. Conserv. Biol. 2, 129-135.

Chan, E.-H., and Liew, H.-C. (1996). Decline of the leatherback population in Terengganu. Malaysia, 1956-1995. Chelonian Conserv. Biol. 2, 196-203.

Chan, E. H., Liew, H. C., and Mazlan, A. G. (1988). The incidental capture of sea turtles in fishing gear in Terengganu. Malaysia. Biol. Conserv. 43, 1-7. doi: 10.1016/0006-3207(88)90074-2

Chan, E. H., Salleh, H. U., and Liew, H. C. (1985). Effects of handling on hatchability of eggs of the leatherback turtle. Dermochelys coriacea (L.). Pertanika 8, 265-271.

Chua, T. H., and Furtado, J. I. (1988). Nesting frequency and clutch size in Dermochelys coriacea in Malaysia. J. Herpetol. 22, 208-218. doi: 10.2307/ 1563999

Farrington, J., Carney, D., Ashley, C., and Turton, C. (2004). "Sustainable livelihoods in practice: early applications of concepts in Rural Area," in Environment, Development, and Rural Livelihoods, eds S. Jones, and G. Carswell, (London: Earthscan), 189-202. 
Ferraro, P. J. (2007). A Global Survey of Sea Turtle Payment Incentive Programs in Project Report. Commissioned by Southwest Fisheries Science Center. Silver Spring, MD: National Marine Fisheries Service

Ferraro, P. J., and Gjertsen, H. (2009). A global review of incentive payments for sea turtle conservation. Chelonian Conserv. Biol. 8, 48-56. doi: 10.2744/CCB0731.1

Frazier, J. (2003). "Prehistoric and ancient historic interactions between humans and marine turtles," in Biology of Sea Turtles, Vol. 2, eds P. L. Lutz, J. A. Musick, and J. Wyneken, (Boca Raton, FL: CRC Press), 1-38. doi: 10.1201/ 9781420040807.ch1

Fretey, J., Segniagbeto, G. H., and Soumah, M. (2007). Presence of sea turtles in traditional pharmacopoeia and beliefs of West Africa. Mar. Turt. Newsl. 116, 23-25.

Garland, K. A., and Carthy, R. R. (2010). Changing taste preferences, market demands and traditions in Pearl Lagoon, Nicaragua: a community reliant on green turtles for income and nutrition. Conserv. Soc. 8, 55-72. doi: 10.4103/ 0972-4923.62675

Grayson, J., Hamann, M., Marsh, H., and Ambar, S. (2010). Options for managing the sustainable use of green turtles: perceptions of Hammond Islanders in Torres Strait. Conserv. Soc. 8, 73-83. doi: 10.4103/0972-4923.62673

Gregory, R., and Sharma, D. S. K. (1997). Status of Federal And State Legislation Affecting Chelonian Conservation in Malaysia. Selangor: WWF-Malaysia.

Guha, R. (2003). "The authoritarian biologist and the arrogance of anti-humanism: wildlife conservation in the third World," in Battles over Nature: Science and the Politics of Conservation, eds V. K. Saberwal, and M. Rangarajan, (Delhi: Permanent Black), 139-157.

Hendrickson, J. R. (1958). The green sea turtle, Chelonia mydas (Linn.) in Malaya and Sarawak. J. Zool. 130, 455-535. doi: 10.1111/j.1096-3642.1958.tb00583.x

Hendrickson, J. R., and Alfred, E. R. (1961). Nesting populations of sea turtles on the East Coast of Malaya. Bull. Raffles Mus. 26, 190-196.

Hendrickson, J. R., and Winterflood, J. S. (1961). Hatching leathery turtle eggs. Bull. Raffles Mus. 26, 187-189.

Humber, F., Godley, B. J., and Broderick, A. C. (2014). So excellent a fishe: a global overview of legal marine turtle fisheries. Divers. Distrib. 20, 579-590. doi: $10.1111 /$ ddi.12183

Ibrahim, K., and Sharma, D. S. K. (2006). "Forty years of sea turtle conservation efforts: where did we go wrong? Lessons learned and the way forward," in Charting Multidisciplinary Research and Action Priorities Towards the Conservation and Sustainable Management of Sea Turtles in the Pacific Ocean: a Focus on Malaysia, eds M. Ahmed, S. Wagiman, K. Ibrahim, S. C. Ho, H. C. Liew, B. H. Yeo, et al. (Penang: The WorldFish Center), 29-34.

Kasmir, W. (2017). Man held over 3,000 turtle eggs in Sandakan. Borneo Post, May 20, 2017.

Keane, A., Jones, J. P. G., Edwards-Jones, G., and Milner-Gulland, E. J. (2008). The sleeping policeman: understanding issues of enforcement and compliance in conservation. Anim. Conserv. 11, 75-82. doi: 10.1111/j.1469-1795.2008. 00170.x

Kent, J. (2006). Malaysia turtle egg plan “crazy”. Kuala Lumpur: BBC News.

King, B. (2011). Spatialising livelihoods: Resource access and livelihood spaces in South Africa. T. I. Br.Geogr. 36, 297-313. doi: 10.1111/j.1475-5661.2010. 00423.x

Klein, C. J., Beher, J., Chaloupka, M., Hamann, M., Limpus, C., and Possingham, H. P. (2017). Prioritization of marine turtle management projects: a protocol that accounts for threats to different life history stages. Conserv. Lett. 10, 547-554. doi: 10.1111/conl.12324

Koch, V., Nichols, W. J., Peckham, H., and de la Toba, V. (2006). Estimates of sea turtle mortality from poaching and bycatch in Bahía Magdalena, Baja California Sur, Mexico. Biol. Conserv. 128, 327-334. doi: 10.1016/j.biocon.2005.09.038

Krantz, L. (2001). The Sustainable Livelihood Approach to Poverty Reduction. SIDA Division for Policy and Socio-Economic Analysis. Available at: https:/www.sida.se/contentassets/bd474c210163447c9a7963d77c64148a/thesustainable-livelihood-approach-to-poverty-reduction_2656.pdf (accessed January 22, 2016).

Kuppusamy, B. (2012). Conservationists Urge Ban on Trade of Turtle Eggs. Rome: Inter Press Service.

Lal, A., Arthur, R., Marbà, N., Lill, A. W. T., and Alcoverro, T. (2010). Implications of conserving an ecosystem modifier: increasing green turtle (Chelonia mydas) densities substantially alters seagrass meadows. Biol. Conserv. 143, 2730-2738. doi: 10.1016/j.biocon.2010.07.020

Lam, T., Ling, X., Takahashi, S., and Burgess, E. A. (2011). Market Forces: an Examination of Marine Turtle Trade in China and Japan. Hong Kong: TRAFFIC East Asia.

Liew, H. C. (2011). "Tragedy of the Malaysian leatherback population: what went wrong?", in Conservation of Pacific Sea Turtles, eds P. H. Dutton, D. Squires, and M. Ahmed, (Honolulu: University of Hawai'i Press), 97-107. doi: 10.1515/ 9780824860196-008

Limpus, C. (1993). Recommendations for Conservation of Marine Turtles in Peninsula Malaysia: a Report to the Department of Fisheries Malaysia and WWFMalaysia. Available at: http://repository.wwf.org.my/technical_reports/R/ RecommendationsForConservationOfMarineTurtlesInPeninsularMalaysia.pdf (accessed June 23, 2017).

Mancini, A., Senko, J., Borquez-Reyes, R., Póo, J. G., Seminoff, J. A., and Koch, V. (2011). To poach or not to poach an endangered species: elucidating the economic and social drivers behind illegal sea turtle hunting in Baja California Sur. Mexico. Hum. Ecol. 39, 743-756. doi: 10.1007/s10745-011-9425-8

Montoya, F., and Drews, C. (2006). Livelihoods, Community Well-Being and Species Conservation: a Guide for Understanding, Evaluating and Improving the Links in the Context of Marine Turtle Programs. San Jose: WWF.

Mortimer, J. A. (1988). Recommendations for a National Strategy on Sea Turtles Conservation in Malaysia: a Report to WWF-Malaysia and WWF-USA. Selangor: WWF-Malaysia

Mortimer, J. A. (1989). Threats to the Survival of Terengganu Sea Turtles and a Review of Management Options: a Report Submitted to the Turtles Sanctuary Advisory Council of Terengganu. Selangor: WWF-Malaysia.

Mortimer, J. A. (1990). Patterns of Nesting Distribution at the Rantau Abang Turtle Sanctuary During the 1989 Nesting Season and Implications for Management of Nesting Turtles: a Report Submitted to the Turtles Sanctuary Advisory Council of Terengganu. Selangor: WWF-Malaysia.

Mortimer, J. A., and Daud, D. (1991). ). Study of nesting density at the Rhu Kudung, Tanjung Batu, Cakar Hutan and Ma' Daerah Beaches of Terengganu with Recommendations for Management of the Turtle Populations. Selangor: WWF-Malaysia.

Murray, C. (2001). Livelihoods research: some conceptual and methodological issues. CPRC Background Paper 5. Available at: https://www.files.ethz.ch/isn/128061/ WP05_Murray.pdf (accessed June 16, 2016).

Place, S. E. (1991). Nature tourism and rural development in Tortuguero. Ann. Tourism Res. 18, 186-201. doi: 10.1016/0160-7383(91)90003-T

Rudrud, R. W. (2010). Forbidden sea turtles: traditional laws pertaining to sea turtle consumption in Polynesia (including the Polynesian Outliers). Conserv. Soc. 8, 84-97. doi: 10.4103/0972-4923.62669

Sardeshpande, M., and MacMillan, D. (2019). Sea turtles support sustainable livelihoods at Ostional. Costa Rica. Oryx 53, 81-91. doi: 10.1017/s003060531 7001855

Sario, R. (2016). Sabah Police Cripple Turtle Egg Smuggling Ring. Petaling Jaya: The Star.

Scoones, I. (1998). Sustainable Rural Livelihoods: A Framework for Analysis. IDS Working Paper 72. Sussex: Institute of Developmental Studies.

Scoones, I. (2015). Sustainable Rural Livelihoods and Rural Development. Winnipeg, CA: Fernwood Publishing.

Shyuji, T. (2015). Did localisation of community-based conservation succeed? A case study on community-based sea turtle conservation in Ma'Daerah Sea Turtle Sanctuary. Jati 20, 94-106. doi: 10.22452/jati.vol20no1.6

Sim, B. H. (2015). Turtle eggs sold in Terengganu are brought in illegally. New Straits Times, May 22, 2015.

Siow, K. T., and Moll, E. O. (1982). "Status and conservation of estuarine and sea turtles in West Malaysian Waters," in Biology and Conservation of Sea Turtles, Proceedings of the World Conference on Sea Turtle Conservation, ed. K. A. Bjorndal, (Washington DC: Smithsonian Institution Press), 339-348.

TRAFFIC Southeast Asia (2009). Survey of Marine Turtle Egg Consumption and Trade in Malaysia. Selangor: WWF-Malaysia.

The Star (2005). Fisheries Department mulls ban on turtle egg trade. Petaling Jaya: The Star.

The Star (2006). Terengganu Traders Selling Turtle Eggs. Petaling Jaya: The Star. The Star (2010). X-Rated Egg Rush in Terengganu. Petaling Jaya: The Star. 
The Star (2011). Poaching Does Occur Along Nesting Beaches in Terengganu. Petaling Jaya: The Star.

The Star (2015). WWF: Ban Selling and Eating of Turtle Eggs. Petaling Jaya: The Star.

Today Online (2015). Photo of M'sia Govt Officials at Turtle Egg Dinner Rattles Sabah Conservationists. Singapore: Today Online.

Toner, A. (2003). Exploring sustainable livelihoods approaches in relation to two interventions in Tanzania. J. Int. Dev. 15, 771-781. doi: 10.1002/jid. 1030

WWF (2014). Marine Turtle Highlights 2013 Report. Gland, Switzerland: WWF. Available at: https://d2ouvy59p0dg6k.cloudfront.net/downloads/marine turtles_highlights_2013_1.pdf

WWF-Malaysia (2010). The Enactment of Comprehensive Federal Legislation for Turtles: Memorandum to Prime Minister of Malaysia. Selangor: WWF-Malaysia.

WWF-Malaysia (2012). WWF-Malaysia Maintains Continued Sale of Turtle Eggs Defeats Conservation Efforts. Selangor: WWF-Malaysia.
WWF-Malaysia (2015). A National Ban on Turtle Egg Sales And Consumption Needed. Selangor: WWF-Malaysia.

WWF-Malaysia (2018). Fighting the Marine Turtle Trade in Malaysia. Selangor: WWF-Malaysia.

Zolkepli, F. (2012). Public Must Not Sell, Buy and Eat Turtle Eggs, Urges WWFMalaysia. Petaling Jaya: The Star.

Conflict of Interest: The authors declare that the research was conducted in the absence of any commercial or financial relationships that could be construed as a potential conflict of interest.

Copyright (c) 2020 Mohd Jani, Jamalludin and Long. This is an open-access article distributed under the terms of the Creative Commons Attribution License (CC BY). The use, distribution or reproduction in other forums is permitted, provided the original author(s) and the copyright owner(s) are credited and that the original publication in this journal is cited, in accordance with accepted academic practice. No use, distribution or reproduction is permitted which does not comply with these terms. 